\title{
FGF14 Gene
}

National Cancer Institute

\section{Source}

National Cancer Institute. FGF14 Gene. NCI Thesaurus. Code C147990.

This gene is involved in development and maintenance of the central nervous system. 